Anna Salamończyk-Mochel

Fundacja GPW, Warszawa, Polska - GPW Foundation, Warsaw, Poland

Sergiusz DęBECKI

Fundacja GPW, Warszawa, Polska - GPW Foundation, Warsaw, Poland

\title{
Projekt szkoleniowy Fundacji Giełdy Papierów Wartościowych: „Pracownicze Plany Kapitałowe - inwestowanie przez całe życie” wyzwaniem edukacyjnym na lata
}

\section{Training Project "Employee's Capital Plans - Lifelong Investments" as an Educational Challenge}

Streszczenie: Podstawą prowadzenia działalności gospodarczej jest wzajemne zaufanie podmiotów tworzących rynek. Jeżeli na rynku panują zdrowe reguły, które dotyczą tak samo wszystkich jego uczestników, oraz obowiązuje dobre prawo gospodarcze, skutkuje to trwałym rozwojem, z którego wszyscy mogą czerpać profity. Działalność edukacyjna jest fundamentem, na którym opiera się zaufanie i wypracowuje się reguły, na które istnieje powszechna zgoda. Fundacja GPW, powołana przez Giełdę Papierów Wartościowych (GPW) w Warszawie, od lat prowadzi działania edukacyjne w zakresie budowania zaufania do rynku kapitałowego. Kieruje ona swoją ofertę do wielu grup odbiorców. W niniejszym artykule zostanie przedstawiony wyjątkowy projekt realizowany przez Fundację w 2019 r.: „Pracownicze Plany Kapitałowe - inwestowanie przez całe życie”. Do tej pory w ramach tego projektu przeprowadzono ponad 400 darmowych szkoleń w największych przedsiębiorstwach w Polsce oraz zorganizowano szereg wydarzeń towarzyszących, m.in. spotkania regionalne, adresowane do mniejszych i średnich przedsiębiorców, w tym kadry zarządzającej. Proces wdrażania Pracowniczych Planów Kapitałowych (PPK) w Polsce stał się okazją do przeprowadzenia szeregu badań na ten temat. W niniejszym artykule powołano się na dane zaczerpnięte $\mathrm{z}$ raportu jednej z najbardziej renomowanych na świecie instytucji audytorsko-doradczych oraz na badania własne Fundacji, pozyskane w procesie ewaluacji szkoleń. Wnioski, które się nasuwają, są wyzwaniem dla całej edukacji ekonomicznej. Zaniechanie pogłębionej i wieloaspektowej działalności edukacyjnej w tym zakresie, adresowanej do różnych grup odbiorców, będzie brzemienne dla całej polskiej gospodarki i dla każdego z nas.

Abstract: The main aim of this paper is to provide remarks on the mutual trust between market mak-
ers and its educational side. If there are fair rules that apply equally to all market participants and
a good economic law, it results in sustainable development from which everyone can profit. In this 
variant economic educational activities, on which this trust is based, are universally agreed upon. The GPW Foundation was established by the Warsaw Stock Exchange and for years has been conducting educational activities in building confidence in the capital market. It directs its offer at many groups of participants. The present article discusses a unique project implemented by the Foundation in 2019: "Employee's Capital Plans - Lifelong Investments". So far, we have conducted over 400 free training sessions in the largest enterprises in Poland, we have organised a number of accompanying events, including regional meetings addressed to small and medium entrepreneurs and management staff. The paper also refers to several data taken from the report of one of the world's most reputable audit and advisory institutions and from the Foundation's own research obtained in the training evaluation process. The conclusions that come from it are a challenge for all economic education, and not undertaking in-depth and multi-faceted educational activities addressed to various groups of recipients will have serious implications for the entire Polish economy and for each of us.

Słowa kluczowe: edukacja finansowa; Fundacja GPW; Giełda Papierów Wartościowych; oszczędzanie; Pracownicze Plany Kapitałowe

Keywords: Employee's Capital Plans; financial education; GPW Foundation; saving; Warsaw Stock Exchange

Otrzymano: 14 listopada 2019

Received: 14 November 2019

Zaakceptowano: 30 maja 2020

Accepted: 30 May 2020

\section{Sugerowana cytacja/Suggested citation:}

Salamończyk-Mochel, A., Dębicki, S. (2020). Projekt szkoleniowy Fundacji Giełdy Papierów Wartościowych „Pracownicze Plany Kapitałowe - inwestowanie przez całe życie” wyzwaniem edukacyjnym na lata. Przedsiębiorczość - Edukacja [Entrepreneurship - Education], 16(2), 347-353. doi: $0.24917 / 20833296.162 .27$

\section{Wstęp}

Fundacja GPW została powołana do istnienia przez Giełdę Papierów Wartościowych (GPW). Cele statutowe organizacji koncentrują się na szeroko rozumianej działalności edukacyjnej, ogniskującej się wokół budowania zaufania do rynku kapitałowego w Polsce oraz do działających na nim podmiotów. Jednym z nadrzędnych zadań GPW jest taka organizacja rynku kapitałowego w Polsce, by był on coraz bardziej przejrzysty i bezpieczny. Co oczywiste, $\mathrm{z}$ inwestowaniem zawsze związane jest ryzyko inwestycyjne, jednak przez dobre prawo gospodarcze, przejrzyste reguły i sprawnie działające mechanizmy może być ono znacząco ograniczone. W tej materii fundamentalnwe znaczenie ma element edukacyjny, w którego rozwój GPW w dużej mierze jest zaangażowana dzięki działaniom podejmowanym przez Fundację. Oferta edukacyjna Fundacji skierowana jest do dzieci, młodzieży i osób dorosłych. Obejmuje ona wiele projektów dostosowanych do aktualnych potrzeb i możliwości odbiorców. Są to m.in.: wizyty edukacyjne i studyjne, Szkolna Internetowa Gra Giełdowa czy Szkoła Giełdowa prowadzona w różnych ośrodkach akademickich na terenie całego kraju. 


\section{Wyjątkowy projekt szkoleniowo-edukacyjny}

Rok 2019 w Fundacji GPW minął m.in. na realizacji ambitnego projektu szkoleniowo-edukacyjnego o nazwie „Pracownicze Plany Kapitałowe - inwestowanie przez całe życie". Projekt ten wynikał z decyzji Zarządu GPW, który po wejściu w życie Ustawy z dnia 4 października 2018 o Pracowniczych Planach Kapitałowych (Ustawa...), postawił Fundacji ambitny cel związany ze skierowaniem w stronę przedsiębiorców merytorycznej, eksperckiej pomocy biznesowej w procesie wdrażania w ich firmach Pracowniczych Planów Kapitałowych (PPK).

Przystępując do realizacji projektu, zrekrutowaliśmy ok. 30 szkoleniowców (w zdecydowanej większości były to osoby współpracujące z nami od lat w ramach projektu Szkoły Giełdowej, często pracownicy naukowi na kierunkach ekonomicznych). Osoby te przez serię warsztatów same dogłębnie zapoznały się z programem PPK. Podjęliśmy też bardzo bliską i merytoryczną współpracę z Polskim Funduszem Rozwoju, została również przygotowana baza materiałów szkoleniowych. Za pomocą zewnętrznej firmy call center udało nam się zbudować dwie bazy danych o dużych przedsiębiorstwach (obecnie powstaje trzecia baza, obejmująca średnie firmy) wyrażających wstępną chęć skorzystania przez kadrę zarządzającą z naszej oferty szkoleniowej w zakresie PPK. Ze względu na charakter działalności Fundacji i ścisłe powiązanie z GPW skupiono się na rzetelnym przekazywaniu zainteresowanym wiedzy z zakresu ogólnego tła gospodarczo-demograficznego - jest to jeden z powodów, dla których ustawodawca wprowadził Pracownicze Plany Kapitałowe do polskiego porządku prawno-gospodarczego (Ocena skutków regulacji..., 2018). Skoncentrowano się również na założeniach programu PPK oraz na jego praktycznym wdrażaniu w przedsiębiorstwach.

W odróżnieniu od wielu innych podmiotów szkolących Fundacja skupia się na bezpłatnym i bezinteresownym edukowaniu zainteresowanych. Przyświeca jej fundamentalna zasada bezstronności w przekazywaniu społeczeństwu wiedzy na temat oszczędzania. Wychodzi przy tym z założenia, że tylko w ten sposób, poprzez systematyczną i sumienną działalność edukacyjną, można zmienić podejście Polaków, które w tym zakresie jest w przeważającej mierze sceptyczne. Co zrozumiałe, podejmując opisane działania szkoleniowe, Fundacja bardzo ściśle współpracuje z GPW. Przyświecają nam te same wartości i wyzwania, które stawia sobie warszawski parkiet. Głównym wyzwaniem jest bycie kreatorem ewolucyjnej zmiany nastawienia coraz większej części społeczeństwa do potrzeby oszczędzania, zwłaszcza polegającego na gromadzeniu i dywersyfikacji środków w perspektywie emerytalnej, oraz odbudowa zaufania do rynku kapitałowego i bycia w nim aktywnym uczestnikiem.

\section{Trochę danych}

W tym miejscu będziemy opierać się na badaniach przeprowadzonych przez renomowaną, znaną na całym świecie sieć audytorsko-doradczą KPMG. Badania te zostały przeprowadzone w 2019 r., podczas wdrażania PPK w przedsiębiorstwach. Raport z badań został opublikowany w październiku 2019 r. Odniesiemy się również do kilku wniosków, które wypływają z badań własnych Fundacji, opartych na anonimowych ankietach przeprowadzonych w ramach ewaluacji naszych szkoleń, przy czym należy zauważyć, że dotychczas odbyło się ponad 400 szkoleń w dużych firmach, zatrudniających ponad 200 pracowników. 
W lipcu 2019 poziom zawansowania we wdrażaniu programu PPK był bardzo zróżnicowany, nawet wśród największych przedsiębiorstw (firm zatrudniających powyżej 250 pracowników) ${ }^{1}$. Jednak większość z nich jako główne wyzwanie związane z wdrażaniem PPK wskazało obawy natury organizacyjnej, szczególnie konieczność dostosowania systemów IT do realizacji programu. Stosunkowo niewielu przedstawicieli firm oceniło, że program będzie cieszył się na tym etapie zainteresowaniem większości pracowników w ich przedsiębiorstwach. Może to mieć również wpływ na ich planowane podejście do wdrożenia PPK w wersji minimalnej, tj. w wymiarze wymaganym przez regulacje prawne bez opcjonalnego rozszerzenia.

Wszystko wskazuje na to, że podejście pracowników do tematu PPK jest w dużej mierze wynikiem dotychczasowych rozczarowujących doświadczeń związanych z programem Otwartych Funduszy Emerytalnych (OFE). Chociaż przyjęta formuła programu PPK jest odmienna od formuły OFE, to poziom nieufności jest bardzo wysoki.

Badania przeprowadzone przez KPMG potwierdzają, że większość pracowników nie miało wciąż wystarczającej wiedzy o PPK. Mimo to 74\% przedsiębiorstw uważało, że pracownicy posiadają wiedzę na temat wpływu PPK na wysokość otrzymywanego wynagrodzenia netto. $47 \%$ ankietowanych firm wyraziło przekonanie, że większość pracowników ich organizacji nie będzie zainteresowana przystąpieniem do PPK, a 62\% przebadanych firm skupiło się na obawach natury organizacyjnej, takich jak m.in. dostosowanie systemów informatycznych organizacji lub wyboru odpowiedniej instytucji finansowej. 92\% ankietowanych organizacji planowało wdrożyć minimalną, wymaganą przez regulacje prawne, wersję PPK, która zobowiązuje pracodawców do wpłaty 1,5\% wynagrodzenia brutto pracownika. Tylko $18 \%$ firm uważało, że zatrudnieni w ich organizacjach pracownicy posiadają wysoką lub bardzo wysoką wiedzę na temat PPK (KMPG, 2018). Zdaniem 8 na 10 firm większość pracowników zatrudnionych w ich organizacjach nie miała wiedzy lub miała średnią wiedzę na temat PPK.

Nieufność?

Do 12 listopada 2019 r., zgodnie z ustawą, najwięksi pracodawcy musieli podpisać umowy o prowadzenie PPK w imieniu pracowników (Ustawa..., art. 8). Średnie firmy szykowały się do wyboru i wprowadzenia PPK. Obowiązek ten objął je od 1 stycznia 2020 r. (Ustawa..., art. 8). Wielu pracodawców zdecydowało się zastąpić PPK Pracowniczym Programem Emerytalnym (PPE). Od stycznia do października 2019 r. Komisja Nadzoru Finansowego (KNF) zarejestrowała około 530 PPE, a w listopadzie regulator rozpatrywał jeszcze ponad 200 wniosków. Dla porównania, w 2018 r. powstało 209 PPE, a w poprzednich latach KNF rejestrowała ich zaledwie 20-40 rocznie (Pracodawcy uciekaja..., 2019).

Skąd nagły wzrost popularności PPE mimo kampanii informacyjnej promującej PPK i faktu, że nie ma merytorycznych podstaw do tego, aby nowy program kojarzyć z OFE? Najwyraźniej PPE nie są obciążone wizerunkowymi problemami OFE. W rezultacie, choć uczestnictwo w PPE wymaga od pracowników złożenia pisemnej deklaracji, a w niektórych firmach czas na podjęcie decyzji był krótki, w nowych programach uczestniczy ok. 70\% pracowników (według KNF w 2018 r. średni poziom partycypacji wynosił 67,7\%) (Pracodawcy uciekaja..., 2019).

\footnotetext{
${ }^{1}$ Wyniki pochodzą z wewnętrznych badań Fundacji GPW przeprowadzonych w ramach wewnętrznego audytu szkoleń, realizowanych w przedsiębiorstwach. Badania nie były wcześniej publikowane.
} 


\section{Wyniki wewnętrznych badań Fundacji}

W czasie badań przeprowadzonych przez Fundację na pytanie: „Które czynniki w Państwa opinii mogą wpłynąć na powszechność uczestnictwa w PPK?”, 72\% kadry zarządzającej uczestniczącej w szkoleniach wskazało na potrzebę bezpośrednich spotkań osób odpowiedzialnych za wdrażanie programu w przedsiębiorstwie z osobami zatrudnionymi, a 56\% wskazało na zbyt niski poziom wiedzy nt. PPK wśród pracowników.

Z kolei odpowiedzi na pytanie: „W jaki inny niż obecnie sposób Fundacja GPW mogłaby pomóc Państwu przy wdrażaniu PPK?” odpowiedzi były znaczące: 58\% przedsiębiorców widziało potrzebę przeprowadzenia dla pracowników szkoleń otwartych połączonych z dyskusją, a kolejne 38\% - przygotowanie dla pracowników broszur informacyjnych o PPK.

Na pytanie: „Jak oceniacie Państwo obecną formę pomocy w postaci szkoleń Fundacji GPW?” 45\% respondentów odpowiedziało, że bardzo wysoko, a kolejne 43\%, że wysoko (badanie przeprowadzone w pięciostopniowej skali). To daje prawie $90 \%$ wysokich ocen zaoferowanej przez Fundację formy szkolenia ${ }^{2}$.

\section{Wnioski z badań}

Analiza powyższych badań pozwala na sformułowanie kilku fundamentalnych wniosków, które są znamienne dla całego rynku kapitałowego, rozwoju gospodarczego i przyszłości Polaków. Istnieje duże prawdopodobieństwo, że przynajmniej w pierwszym okresie PPK zostaną zaimplementowane tylko w tym zakresie, który jest wymagany ustawowo. Do zmiany tego podejścia, tak po stronie pracodawców, jak i pracowników, potrzeba będzie długofalowej pracy edukacyjnej. Z wyników przeprowadzonych badań wynika też, że pracownikom brakuje podstawowej wiedzy na temat PPK. Ci, którzy z nimi na co dzień pracują (kadra zarządzająca), widzą potrzebę bezpośrednich, eksperckich spotkań, dostosowanych do możliwości organizacyjnych przedsiębiorstw, jak i do różnych grup oraz poziomu odbiorców. W tej kwestii konieczne wydaje się również opracowywanie szeregu narzędzi i materiałów, które mogą pomóc jak największej grupie obywateli czynnie uczestniczyć w programie oszczędzania.

W minionych latach zamieszanie spowodowane przekształceniami w OFE spowodowało, że każdy kolejny projekt, nawet słuszny, który wprowadza państwo, stwierdzając, że te pieniądze są już na pewno własnością jego posiadacza odkładaną na czas emerytury, spotyka się ze sceptycyzmem. Naruszonego zaufania do tak fundamentalnej kwestii umowy społecznej, jaką są przyszłe emerytury i oszczędzanie, nie da się inaczej odbudować, jak poprzez edukację w zakresie rynków kapitałowych, finansów i przedsiębiorczości. I jest to praca na lata i na każdy etap rozwojowy, poczynając od obecnych uczniów, a kończąc na tych, którzy tworzą rynek pracy.

Realizacja projektu „Pracownicze Plany Kapitałowe - inwestowanie przez całe życie” to dla Fundacji unaocznienie, jak wielką wartość mają działania podejmowane na polu edukacji ekonomicznej skierowane do odbiorców z pozycji bezstronnego eksperta. Będąc niejako reprezentantami GPW, skupiliśmy się na wysoko merytorycznym przekazie

\footnotetext{
${ }^{2}$ Wyniki pochodzą z wewnętrznych badań Fundacji GPW przeprowadzonych w ramach wewnętrznego audytu szkoleń realizowanych w przedsiębiorstwach. Badania nie były wcześniej publikowane.
} 
informacji, dzięki czemu przygotowaliśmy solidne przedpole do osobistych decyzji tak po stronie pracodawców, jak i pracowników. Nic nie jest w stanie skuteczniej zmieniać nastawienia niż rzetelność i profesjonalizm. Doświadczenie, które nabyliśmy w tym zakresie, przeprowadzona ewaluacja szkoleń i jej analiza to dla nas skarbnica nowych pomysłów w obszarze edukacji ekonomicznej, adresowanych do różnych generacji naszego społeczeństwa.

\section{Podsumowanie}

Przybliżenie czytelnikom realizacji jednego z projektów Fundacji GPW „Pracownicze Plany Kapitałowe - inwestowanie przez całe życie” to dobry przyczynek do podjęcia głębszej refleksji nad ukierunkowaniem edukacji związanej z oszczędzaniem i naszą złożoną sytuacją w systemie emerytalnym. Warto, aby nauczyciele przedmiotów, w ramach których przekazywane są ekonomiczne treści, uwzględnili kwestie związane z koniecznością oszczędzania $z$ horyzontem emerytalnym oraz dostrzegali walor kumulacji kapitału, który z kolei może być inwestowany w gospodarkę, przyczyniając się tym samym do jej rozwoju. Potężne deficyty społecznego zaufania w kwestiach kreowanej przez państwo polityki oszczędzania oraz braki elementarnej wiedzy w tym zakresie pozwalają stwierdzić, że tylko wypracowywanie adekwatnych narzędzi, cierpliwość oraz dostosowanie przekazu do zróżnicowanego odbiorcy mogą pomóc w zmianie tego stanu rzeczy. Wydaje się, że pozytywne zmiany w tym względzie będą możliwe w przyszłości, jeśli już teraz zaprezentowana problematyka zostanie włączona w cały proces edukacyjno-wychowawczy najmłodszych Polaków.

\section{Literatura}

References

KMPG. (2019). Pracownicze Plany Kapitałowe. Wyzwania firm zwiazane z wdrażaniem PPK. Pozyskano z: https://assets.kpmg/content/dam/kpmg/pl/pdf/2019/10/pl-Raport-KPMG-pt-Pracownicze-Plany-Kapitalowe-Wyzwania-firm-zwiazane-z-wdrazaniem-PPK.pdf

Ocena skutków regulacji Projektu ustawy o pracowniczych planach kapitałowych. (2018). http://www. znpul.pl/wgrane_pliki/osr-ustawy-o-ppk.pdf

Pracodawcy uciekaja przed PPK w PPE. (2019, 13 listopada). Pozyskano z: https://serwisemerytalny. $\mathrm{rp} . \mathrm{pl} /$ pracodawcy-uciekaja-przed-ppk-w-ppe/

Ustawa z dnia 4 października 2018 o Pracowniczych Planach Kapitałowych. DZ.U. 2018, poz. 2215.

Anna Salamończyk-Mochel, prezes Fundacji Giełdy Papierów Wartościowych.

Anna Salamończyk-Mochel, President of the GPW Foundation.

\section{Adres/Address:}

Fundacja Giełdy Papierów Wartościowych

ul. Książęca 4

00-498 Warszawa, Poland

e-mail: anna.salamonczyk@fundacjagpw.pl 
Sergiusz Dębecki, koordynator projektu „Pracownicze Plany Kapitałowe - inwestowanie przez całe życie”, specjalista ds. projektów edukacyjnych, Fundacja Giełdy Papierów Wartościowych.

Sergiusz Dębecki, project coordinator of “Employee’s Capital Plans - Lifelong Investments”, project specialist, GPW Foundation.

\section{Adres/Address:}

Fundacja Giełdy Papierów Wartościowych

ul. Książęca 4

00-498 Warszawa, Poland

e-mail: sergiusz.debecki@fundacjagpw.pl 